\title{
Drivers and difficulties in the economic relationship between Australia and the European Union: from conflict to cooperation
}

Gonzalo Villalta Puig

\section{ABSTRACT}

Economic relations between Australia and the European Union (EU) have always been strong, but they have not always been easy. They have been difficult for Australia because it associated the EU with the loss of the UK preferential export market on its entry into the then European Economic Community. And because Australia associated the EU with the original Common Agricultural Policy, which combined subsidies for agricultural production and high agricultural tariffs to make Australian agricultural exports not competitive. They have been difficult for the EU also. Australia developed a biosecurity system to protect its agricultural sector: quarantine requirements and food safety standards made the importation of EU plant and animal products too costly. Yet Australia and the EU need each other. The EU, which is Australia's largest services trade and investment partner, supplies the business services that drive a knowledge economy and provides the credit to finance economic development. Correspondingly, the EU needs Australia both as a commercial base in Asia and as a reliable energy supplier. This article analyses the drivers and difficulties in the economic relationship between Australia and the EU as they start negotiations for a free trade agreement.

\section{Introduction}

The European Union (EU) remains Australia's largest economic partner. While China, Japan and South Korea are now larger merchandise markets, the EU is still Australia's largest partner in twoway services trade and its largest investment partner. Economic relations between Australia and the $\mathrm{EU}$ are strong. That strength, however, does not make them easier. Regular disagreement on the scope of trade in agricultural goods and the role of biosecurity and safety standards has made economic relations between Australia and the EU difficult. This article seeks to analyse both the drivers and difficulties of the relationship now that Australia and the EU have launched negotiations for a free trade agreement (FTA). It argues that, after decades of disagreement over the balance between free trade and trade protection, Australia and the EU finally recognise each other as close economic partners with a joint commitment to deep and comprehensive economic integration with regional value chains.

\section{Drivers and difficulties in the Australia-EU economic relationship}

The EU continues to be Australia's largest economic partner. The value of trade and investment between Australia and the EU is greater than that of any other bilateral relationship that Australia has with other economies (DFAT 2016, 6). The EU is now only Australia's third-largest partner in twoway goods trade-China and Japan are larger partners-but it remains Australia's largest partner in two-way services trade, as well as Australia's largest investment partner (Delegation of the European Union to Australia 2013b, 2; DFAT 2015, 3).

Australia's profile as a services economy in the Asia-Pacific region makes it a strategic base for EU corporations with markets in that region, which explains the EU's large share of foreign direct 
investment stocks in Australia, the value of which exceeds that of EU goods and services exports to Australia. Bilateral investment flows have financed the establishment of $2400 \mathrm{EU}$ corporations in Australia, which, in turn, have created almost 1.5 million indirect jobs and, as of December 2014, over 376,000 direct jobs (Delegation of the European Union to Australia 2013a, 7; DFAT 2015, 3). Conversely, Australia's cultural affinity with Europe makes the EU an easy place to do business (two million Australian residents were born in EU member states).

And unlike in its relations with China, Japan or South Korea, Australia does not solely rely on the export of coal and iron in its relations with the EU. Primary products account for a relatively small share of bilateral trade in goods. Elaborately Transformed Manufactures account for the biggest share in that mix, which makes the value of two-way trade much less susceptible to commodity price fluctuation. Thus, in 2016-17, Australia's coal exports to the EU were worth AU\$4,206,123, whereas the EU's car exports to Australia were worth AU\$6,682,192-(DFAT 2018, 125).

The Australia-EU economic relationship is, moreover, knowledge-led because it relies so much on trade in services. Services represent more than 30 percent of the value of trade between Australia and the EU, a higher figure than the value that services have in Australia's relationship with China and Japan, its two largest merchandise partners. While the trade flow is mostly one-way-Australia has a services trade deficit with the EU (DFAT 2016, 48-49) - the larger share of services in the composition of trade between Australia and the EU is positive for economic development, especially so for Australia, which must diversify its economy beyond primary products if it is to promote higher value-added-margin commercial activities.

Despite the size of the economic relationship, the EU is no longer Australia's largest trading partner and the value of two-way trade has not grown too much in recent years (only 1.3 percent growth on a five-year trend; DFAT 2016, 35). While this slowdown has prompted the two sides to revive their trade relations through negotiations for greater market access under an FTA, the prospect of a closer economic partnership may not come true if the negotiations do not properly address the difficulties in the Australia-EU economic relationship.

The Australia-EU economic relationship 'has not always been a smooth one' (Kenyon 2012, 34). Often, it has been rough, largely because of the place of Australia in the UK and the place of the UK in the EU (Kunkel 2003). With the accession of the UK to the then European Economic Community in 1973, Empire Free Trade ceased for Australia (Kenyon 2012, 35) and the pace of its wheat, sugar, fruit, beef, sheepmeat, wool and dairy exports slowed down. The EU's Common Agricultural Policy (CAP) almost brought it to a halt. It pushed Australia out of the EU's agricultural market and into the beef and wheat markets of Asia (Gelber 1966), in particular China (Benvenuti 2007). Australia had no other option but to move its trade eastwards. Moreover, it was in this period that Australia began to develop a science-led biosecurity system of quarantine requirements and food safety standards.

It was as if, in the collective unconscious, Australia blamed Europe for its orphanhood from the mother country. This reaction prompted a political instinct to protect the land, which the 
conservative coalition in the Australian government was only too happy to foster. At its height in the late 1970s, it invited the then National Country Party-now the National Party of Australia-to assume the trade portfolio. The Nationals (2016) no longer manage the trade portfolio but their influence on trade policy remains notable.

Perhaps because Australia idealised agriculture as 'the backbone of the country' (Burnett 1983, 2), agriculture remains a political concern. The concern is not entirely without justification. Australia does export the bulk of its agricultural production-approximately 65 percent (DFAT 2012, 26)-and rurals such as beef and wheat are Australia's highest-value goods export after minerals and fuels (DFAT 2016). The concern is largely attributable to the CAP-what remains of it. Through an import tariff and quota system and an export subsidy scheme (European Commission 2010a, 14), the CAP caused both oversupply and price increases which, together, blocked out competition from Australia between the 1960s and 1990s. While the CAP of the Europe 2020 reforms is not as protectionist, Australia still wants the EU to further liberalise agricultural trade (Kenyon and Lee 2006; European Commission 2010b), both as permanent chair of the Cairns Group and as a member of the World Trade Organization (WTO; Benvenuti 1999).

'Australia's unidimensional policy pre-occupation with the CAP' (Murray 2002, 161) has certainly not won the EU's favour. John Howard, a former conservative prime minister of Australia, championed a firm diplomacy as Minister for Special Trade Negotiations with the European Communities in the late 1970s (Ward 2002, 187). Recalling that period, Roy Jenkins $(1989,272)$, a former president of the European Commission, observed: 'We wanted to improve relations with Australia but we would be damned if we would be bullied into doing so'. More recently, Mark Vaile (2004), a former leader of the Nationals and Minister for Trade in the Howard government, blamed the EU for the 'current inequities towards agriculture in world trade'. Not surprisingly, Brendan Nelson (2013), a former Ambassador of Australia to the EU, complained at the inefficacy of that firm diplomacy: 'traditionally in Brussels what we had done is just bang them over the back of the head about agriculture and market access'.

It has not been pragmatic either. Historically, Australia has needed trade with the EU more than the EU has needed trade with Australia (Burnett 1983, 3). Still today, Australia is only 'a minor trading partner for the EU' (Murray 2003, 72). Indeed, until the release in October 2015 of 'Trade for All', the European Commission's $(2015,24)$ latest trade and investment strategy, Australia made relatively little progress in the advancement of a closer economic partnership with the EU. The KerinAndriessen Accord of 1985-whereby the EU would not sell subsidised beef to Australia's markets in Asia-was a small win for the Australian government (Kenyon 2012 Kenyon, Donald. 2012. "Australia and the European Union: A Relationship Driven by Trade." In No Eutopia: The European Union Today edited by Australian Institute of International Affairs, 33-42. Canberra: Australian Institute for International Affairs.

,36). Years later, in 2010 , the Australian government scored another small win when it secured an additional tariff quota for the import of grain-fed high-quality beef into the EU, only because 
'Catherine Ashton had a very good relationship as Trade Commissioner with Simon Crean [the then Australian Minister for Trade]' (Nelson 2013).

Australia is certainly no longer a 'branch office of Empire' (Higgott 1994), and the days of protectionist 'Fortress Europe' (DFAT 1989, 13) are certainly in the past. The Australian government has changed and is changing its position on the CAP. Australian farmers are already gaining better, 'fairer' (Fischer 1996) access to the EU market (DFAT and Austrade 1996, xv, xvi). The European Commission has decoupled subsidies from product support to producer support (Glyde 2008), partly in response to a successful complaint brought by Australia against the EU in the WTO (2005). Agriculture is a less important concern now that Australia and the EU share a commitment to liberalise agricultural trade under the Doha Development Agenda. With the entry into force in 1995 of the WTO's Agreement on Agriculture, agricultural subsidies have steadily come down across the world, permitting Australia to export agricultural products to the EU in a commercially viable manner (Murray 2005, 118). 'Australia's preoccupation with the CAP cannot obfuscate reality' (Raffin 2007, 143). The EU is the world's largest importer of agricultural products. Nevertheless, if not a concern, agriculture is still sure to be a key issue in the bilateral relationship: Australian beef exporters object to the EU's tariff-rate quotas while the EU's food and beverage industries object to Australia's approach to geographical indications (Gls).

Naturally, 'the "blow-out" in Australia's trade deficit with the EU' does not alleviate concerns (Murray 2005, 73). The deficit suggests a lack of balance in the economic relationship between Australia and the EU: the EU sells more to Australia than Australia sells to the EU. That lack of balance is the result not only of EU trade policy, but also of Australian trade policy. The EU considers that Australia's biosecurity policy regime is a protectionist device. Australia's assessment procedures, quarantine standards and other technical barriers, as well as the use of European place names for its food products, are problematic for the EU. For a former European Commissioner for Agriculture, Franz Fischler, exporting to Australia is 'like going through the biblical eye of the needle' (Harding 2000). Australia's biosecurity laws are costly to administer for EU exporters. Australia's biosecurity standards have often been the subject of complaint by the EU in the WTO (WTO 2011, 27[172]). The EU's complaint is that Australia covers its trade protectionist purposes under the mantle of environmental protection (Oxley 2002, 112), whereas Australia claims that the importation of live animals and animal products (raw meat is the major concern) could introduce European animal diseases. Thus, Australia and the EU must work to remove all regulatory divergences in these areas (Kenyon and Lee 2011, 118). FTA negotiations would provide the ideal forum-indeed, the inclusion of a chapter on veterinary arrangements could facilitate market access for EU animal-product exporters.

\section{A new framework for a closer economic partnership}

While Australia and the EU have strengthened their trade relations in recent years, their relationship is significantly more difficult than it is with Asia. EU tariffs-notably, agricultural tariffs-are comparatively high, and behind-the-border barriers to services markets are high too. Ironically, 'many Australian exporters see themselves as facing more impediments to trade in the EU than in Asia' (DFAT and Austrade 1996, 87). After all, while Australia and the EU are still to conclude an FTA, Australia already has FTAs with China, Japan and South Korea, as well as Singapore, Malaysia and 
Thailand. Asia has an additional advantage over the EU: economic expansion. In order to fuel and build that economic growth, Asia needs what Australia has: coal and steel.

Australia, therefore, has, in recent decades, turned to Asia (Australian Government 2012, 81). It must not, however, turn away from the EU (Richardson 1992, 208, 218), not only because of the importance of EU services trade and investment to Australia, but also because of the significance of the EU as a leader of world trade policy developments, which, inevitably, do affect Australia. Moreover, as Australia's former Governor-General, Quentin Bryce (2013), once remarked: 'Asia's rise increases the importance of Australia's ties with Europe'. As a large source of primary products, Australia does indeed have a major role to play in the economic development of Asia, making it a strategic ally for the EU's business presence in the region (Murray 2008). Australia, in fact, functions as a regional base for dual-listed corporations, as well as Australia-EU research and development joint ventures (DFAT and Austrade 1996, xiii).

There is indeed 'a great need to expand the diversity and the volume of [Australia's] trade and investment links with the EU's member states' (Crean 2008). The cultural links that join Australia and the EU can be an incentive. Australia should appeal to EU tourists wishing to explore an exotic environment within a largely European culture. Australia, too, should appeal to EU students wishing to learn about Asia from the convenience of an English-language medium. Tourism and education are increasingly important to the bilateral trade relationship.

At the same time, the EU is Australia's largest source of foreign-direct and indirect-investment. EU investment stocks fund a large proportion of Australia's manufacturing and services industries. EU corporations with an Australian presence invest heavily in the type of industries that Australia should develop if it is to depend less heavily on the always unstable commodities market. Australia, for example, affords multiple defence materiel procurement opportunities, which actively request tenders from EU government contractors. Many other Australian industries, including infrastructural projects, information and communications technology, biotech, and clean and renewable energy firms, welcome EU investment.

The EU is also a major supplier of capital equipment, industrial machinery and goods vehicles, all of which are essential for Australia's commodity industry. Importantly, Australia needs the EU's emerging technologies to back its research and development efforts in such areas as sustainable and renewable energy and carbon capture and storage in order to develop a high value-added economy.

Overexposure to China and the recent raw materials price slump ("Good on You" 2016) show that diversification is necessary. For Alan Burnett (1983, 3, 119), Australia has, historically, been 'an economic hewer of minerals and cultivator of fibres and foodstuffs for the major industrial countries'. It is a 'first world culture with a third world economy', wrote Alan Oxley $(2002,108)$. Australia is an old, not a new economy: it raises plants (wheat and wine) and animals (beef), and digs stuff (iron and aluminium ores, coal, gas, gold, petroleum) out of the ground ("Something Old" 2000). Rural goods, minerals and fuels still comprise more than half of Australia's exports (DFAT 
$2015,2)$. For that economic shift from extractive industries to manufacturing industries, Australia needs the EU. The pattern that arises from the last two decades of Australia-EU trade relations indeed points to a shift from Simply Transformed Manufactures to Elaborately Transformed Manufactures, and from unprocessed goods to processed goods (Murray 2005, 73). This shift has the support of the Science and Technology Cooperation Agreement between Australia and the EU, which promotes research collaboration between the two sides.

The EU's comparative advantage is its single market, an economy of scale that 'reduces the costs for compliance and increases the potential sales area' (Murray 2005, 70). The EU merges 27 national economies (without the UK) into the world's largest trading bloc: a market of over 500 million consumers. Australia is only a market of 24 million consumers. Ultimately, the EU 'needs Australia ... a great deal less than Australia needs Europe' (Ward 2002, 191). Australia, because of its geographical isolation, small economy, political stability and deference to the USA (Murray 2005, 92), has only ever been a low priority for the EU (Raffin 2007, 142). For Australia, too, ever sensitive to Asia and the USA, the EU has not been a high priority. For both sides, the priority was elsewhere. The approach is different now. The EU seeks to integrate ever more closely with the Asia-Pacific region, and so it is eager to partner with Australia for its close links with value chains in the region (Barroso and Van Rompuy 2013). Australia is also eager to partner because it recognises that, as a 'pioneering regional economic institution for the regulation of transnational trade', the EU sets the world's trade agenda (Saunders and Triggs 2002, vii). Indeed, it was Tony Abbott, the former prime minister, who first proposed a trade and investment agreement to the EU through his UK counterpart, David Cameron, at the 2014 Group of Twenty summit in Brisbane.

On 7 August 2017, Australia and the EU signed a Framework Agreement. This instrument is a treatylevel upgrade to their earlier declarations for collaboration: the Joint Declaration on Relations between the European Union and Australia of 26 June 1997 and the Australia-European Union Partnership Framework of 29 October 2008. The Framework Agreement covers dialogue and cooperation on economic and trade matters. It is not, however, an FTA. The Framework Agreement is no more than an agreement to agree. It is a convenient declaration of the kind of general principles that the parties would like a prospective FTA to revolve around-namely, the primacy of the WTO's multilateral trading system.

Sectoral agreements - whether in relation to science, air services, wine, the security of classified information, conformity assessment procedures for industrial products or the exchange of air passengers' data-are not an FTA either. Their function is to manage aspects of the trade relationship, not to lower tariffs, harmonise standards, give access to the services market or protect investment and, thereby, free trade. Yet, the EU is the only major trading partner with which Australia does not have an FTA. Australia has an FTA with China, Japan, South Korea and even the USA, but not with the EU. Correspondingly, the EU (ever confident with its Common Commercial Policy exclusive external trade competences under the Treaty of Lisbon-more so after Opinion 2/15 of the Court of Justice of the EU) has FTAs with Canada and South Korea, among other trading partners of a similar economic profile to Australia. Australia and the EU need to have an FTA to regulate their bilateral trade relationship, if only to be in alignment with other competing markets. 


\section{An ambitious and comprehensive FTA between Australia and the EU}

Now that Australia and the EU have gained much positive experience in the negotiation and conclusion of FTAs, there is space in the policy agenda for a more active management of the bilateral economic relationship. Further to a joint statement on 22 April 2015 by the High Representative of the European Union for Foreign Affairs and Security Policy and the Australian Minister for Foreign Affairs, which acknowledged the need to strengthen the bilateral economic relationship, at the 2015 Group of Twenty summit in Antalya, the president of the European Commission, Jean-Claude Juncker, the president of the European Council, Donald Tusk, and the prime minister of Australia, Malcolm Turnbull, issued a joint statement to announce their agreement to commence work towards the launch of negotiations for an FTA: 'We will aim to achieve a comprehensive and balanced outcome that liberalises trade, promotes productive investment flows and enhances the regulatory environment for business' (European Commission, European Council and Australian Government 2015).

The European Council, which on 27 November 2015 called on the European Commission to progress preferential trade and investment negotiations in the Asia-Pacific region, will shortly authorise the opening of negotiations for an FTA with Australia (European Commission 2017c European Commission.). The European Parliament has already passed resolutions on the draft negotiating mandates. The Australian government will shortly also authorise the opening of negotiations. Negotiations should take between two and three years to complete, although the aim is to reach completion by 2019 .

Australia and the EU will not start their FTA negotiations with a blank sheet. The two sides have made progress through the Framework Agreement and, more widely, through their collaborative work on trade facilitation for the WTO and the Trade in Services Agreement negotiations. The two sides have also completed a joint scoping exercise to decide how comprehensive the deal is to be. They have consulted with stakeholders and conducted impact assessments and ex ante studies.

The EU has even released its draft negotiating directives, for the first time ever. The EU's objectives are to progressively and reciprocally liberalise substantially all trade in goods and services and foreign direct investment. Those objectives break down into separate sectors. For trade in goods, the objectives all revolve around increased liberalisation:

The aim of the Agreement should be to dismantle import duties and charges having an equivalent effect on both sides ... [S]pecific provisions should cover ... agricultural products for which tariff rate quotas [and] longer transitional periods ... should be considered (European Commission 2017a, 3).

The EU seeks to cover trade-related regulatory issues and other non-tariff barriers. It also seeks to cover rules of origin, anti-fraud measures, the management of administrative errors, customs and trade facilitation, technical regulations, standards and conformity assessment procedures, sanitary and phytosanitary measures, animal welfare, safeguards, and anti-dumping and countervailing 
measures. In the coverage of these various areas, the EU proposes to follow the principles of proportionality, no undue restriction, transparency, non-discrimination, harmonisation and the recognition of equivalence.

For trade in services, the EU is equally ambitious: 'the Agreement should have substantial sectorial coverage and should cover all modes of supply ... other than the exclusion of audio-visual services and services supplied and activities performed in the exercise of governmental authority' (European Commission 2017a, 6). The EU hopes to cover the digitalisation of trade in services and the entry and stay of natural persons for business purposes in a spirit of mutual recognition.

Other areas that the EU hopes to cover in the FTA negotiations include: the removal of restrictions to current payments and capital movements; the promotion of an adequate and effective level of protection and enforcement of intellectual property rights; direct protection of a list of Gls; comprehensive and improved access to public procurement of goods, services and public works at all levels of government and state-owned enterprises now that Australia will finally enter into the WTO's Government Procurement Agreement; the development of competition rules against monopolies; information-sharing arrangements on market access requirements to assist small and medium-sized enterprises; labour and environmental protections in the interest of sustainable development; open trade in energy and raw materials; transparency of regulations; and regulatory cooperation. Australia has not released its negotiating directives, but its objectives are likely to be very similar to those of the EU. The Australian government's Minister for Trade, Tourism and Investment, Steven Ciobo (2017 Ciobo,), has stated that Australia would like the FTA to be 'comprehensive, liberalising and ambitious'.

Ciobo has acknowledged, however, that '[n]egotiations on the FTA will undoubtedly be complex' (ibid.). Both sides have relatively high tariffs with tariff peaks in agriculture and non-tariff barriers around different rules and food industry interests and environmental concerns. Negotiations, then, are not likely to be easy because of 'agricultural sensitivities' (European Commission 2017b, 2). Market access is important to Australian farmers, while subsidies are important to EU farmers. As an example, Australian beef exporters, who come under a tariff-rate quota (either the High Quality Beef Hilton or High Quality Beef Grainfed quota), would face opposition from Irish and other EU beef producers, who rely on subsidies-notably, the EU is Australia's highest-value beef export market. Subsidies are a pervasive problem for Australia as its recent anti-dumping action in the WTO against Italian tinned-tomato makers shows. Conversely, the French, Italian and Spanish food and beverage industries would be sure to raise their concern with Australia's appropriation of European Gls (Miller 2016).

In relative terms, agricultural trade may not be commercially significant-since the bilateral trade relationship is mainly about commodities, education, tourism and investment-but it is politically significant. After all, many Australians mythify farmers as the guardians of the national spirit, while large EU member states such as France, Italy and Spain base so much of their national culture on food. These revelations beg the question: If food production is not economically important for Australia and the EU relative to the totality of their relationship, why is it so special? There are many explanations to account for why food has been so controversial and difficult to negotiate in FTAs bilaterally, regionally and at the WTO level. The first and most persuasive explanation appears to be 
the unique emotive value that humans give to food, given its significance to survival and culture; it affects every person, every day (Bhala 2008, 69). Secondly, food security has historically been a critical component of a country's self-sufficiency. Electoral politics play a major role, too.

Representative democracies like Australia and France allow a disproportionate presence in the legislature to small rural and farming concerns. Because of the strength of the agribusiness lobbies, these polities have a long history of agricultural protection with supporting policies and payments that are almost impossible to remove without electoral harm. A third reason why compromise on agricultural policies has been so difficult is because of the technical difficulty inherent in the negotiation and conclusion of framework agreements for commodities (ibid.). Non-economic reasons also apply, such as stewardship of the countryside, environmental sustainability and social advancement. The point is that food production is a sensitive topic: 'Most governments share a concern for the security of their country's food supply and the level and stability of the income of their rural sector' (Josling 2009, 143).

Of course, the concern with self-sufficiency need not be without sophistication. Australia and the EU often justify such protectionist measures as production subsidies, high tariffs or complex rules of origin with great nuance. The concern for the governments of Australia and the EU is not with selfsufficiency perhaps but with the multifunctionality of agriculture itself: food safety, environmental protection, rural development, landscape preservation or employment retention. Be it a trade concern or a non-trade concern, the response to trade in agriculture is almost always the same: to bar it (Villalta Puig and Mitbrodt 2014, 181-183).

On that note, Australia's science-led biosecurity system of quarantine requirements and food safety standards is sure to dominate FTA negotiations. Australian tariffs are comparatively low at an average applied most-favoured-nation (MFN) rate of 3.0 percent in 2014 (WTO 2015), and so most barriers to trade in goods come in the form of sanitary and phytosanitary measures. As the European Commission's Market Access Database $(2007,183$ ) suggests, Australia's biosecurity assessment procedures and quarantine standards are often the subject of complaint by the EU in the WTO. The complaint is that Australia covers its protectionist intent under the cloak of environmental protection. Australia claims that the importation of raw meat, in particular, risks the outbreak of mad cow disease and foot-and-mouth disease. Discretion to negotiate is narrow as Australia would want to maintain its reputation as a clean country. Once a disease such as fire blight infects an agricultural environment, the economic cost could be unsustainable.

As for behind-the-border barriers, Australia's occupational health and safety laws, workers' compensation system and state taxes, such as the payroll tax, are all obstacles for a fluid FTA negotiation. In many areas of the economy, Australia faces greater duplication and overlap than the whole of the EU (Villalta Puig and Zeller 2016; Villalta Puig 2014, 2016 Villalta Puig, ). Australia's split trade and professional licensing regime shows that the country still does not have a seamless national service economy (Villalta Puig 2008 ). The Business Council of Australia has continually called for the creation of a truly national market because 'as barriers to international trade and investment fall, the relative impact of internal trade barriers increases' (BCA $2008,10,13)$. The White Paper process on the Reform of the Federation agrees: 'Having multiple governments ... can frustrate the efficient operation of national markets' (Department of the Prime Minister and Cabinet 
2014, 2). The development by the Council of Australian Governments of a National Partnership Agreement to Deliver a Seamless National Economy is an intergovernmental acknowledgment of the economic value of free trade as the paradigm of competition (Villalta Puig 2018, 300-301). More generally, the choice of mode of supply for the delivery of services under the General Agreement on Trade in Services is a paramount consideration for the EU (Findlay 2009). Modes of supply that involve either foreign investment or migration would be the subject of highly political, difficult negotiations. Technical barriers are almost unavoidable, particularly for suppliers of professional services whose qualifications must meet the relevant requirements in their target jurisdiction. Architects are a case in point. Australia's service suppliers have to deal with the myriad of recognition requirements on non-EU professions and trades. Mutual recognition of professional and trade qualifications is an issue for both sides. Thus, a prospective FTA would require state-level regulatory reform of the service economy in the same way that Canada's Provinces and Territories responded under the Comprehensive Economic and Trade Agreement (CETA) with the EU.

In relation to investment, Australia applies through its Foreign Investment Review Board severe foreign investment monetary thresholds in the real estate and mining industries. Such restrictions and conditions hinder EU capital flows into green-field investment opportunities in Australia. An FTA would maximise the volume of productive investment flows.

As for the EU, even though its average applied MFN rate for industrial products was 4.3 percent in 2016-only a little higher than the Australian average of 3.3 percent in 2014 (WTO 2015, 9[14], 2017, 48[3.35]) - overall, its average applied MFN rate was 6.3 percent in 2016, which more than doubles the Australian average of 3.0 percent in 2014 (WTO 2015, 8[7], 2017, 48[3.35]). In other words, the EU has higher tariffs than Australia. Their removal would add real value to the bilateral trade relationship since Australian exporters and manufacturers would find it easier to place their goods in EU markets at competitive prices. This point especially applies to Australian farmers. EU market access is very costly for Australia's agricultural products. The EU average applied MFN rate for agricultural goods was 14.1 percent in 2016, which does not compare at all favourably with Australia's tariff rate of 1.4 percent in 2014. Moreover, fruit and vegetables, cereals, sugar, meat and dairy come under excessive tariff-rate quotas (WTO 2015, 9[14], 2017 WTO, 48[3.35]). Australian farmers always fill their country-specific quotas and, despite potential EU customer demand, abovequota market access is too costly because import duties are so high. An FTA could easily lower, or even remove, tariffs.

An ambitious FTA would have a broadly positive impact on aggregate economic trends and welfare effects. The European Commission's ex ante study of the proposed Australia-EU FTA projects positive effects on gross domestic product (GDP) for both Australia and the EU, an increase in bilateral foreign direct investment flows, government procurement gains, lower entry and operating costs for small and medium-sized enterprises, positive long-term welfare and wage effects, lower consumer prices and better consumer information (Directorate-General for Trade 2017, 6-7). It specifically projects a stronger real GDP growth in Australia ( 0.20 percent) than the EU (0.02 percent), although, in relative terms, EU exports to Australia are likely to increase more than Australian exports to the EU. On balance, Australia and the EU would both gain from an FTA, but Australia would gain slightly more than the EU. In that respect, the ex ante study projects a 
concentration of negative externalities in EU primary agricultural industries-specifically, small dairy, beef, lamb and mutton producers, who may experience transitional unemployment (3). In comparison, EU wine and other high-quality agricultural producers are likely to win significant gains, as are EU manufacturers in most sectors (who maybe will even secure the removal of Australia's Luxury (ar Tax). The Australian government has not yet released any impact assessment studies of its own. Nevertheless, Australian agribusinesses have certainly been vocal and outnumber the submissions to the Australian government's Department of Foreign Affairs and Trade on the prospective FTA.

In summary, an Australia-EU FTA has the potential to harmonise the regulatory divergences that arise from the policy disagreement over biosecurity (quarantine requirements) and agriculture (tariff-rate quotas). For trade in goods, tariffs are generally low but behind-the-border barriers remain high, especially in relation to inconsistent safety standards. For trade in services, the nonunitary constitutions of Australia and the EU continue to make professions and trades dependent on protectionist subnational regulation. Agriculture is no longer a priority for both sides, but it still has the potential if not to block, then certainly to interrupt what should be a practical negotiation.

\section{Brexit and CETA}

Apart from the commercial issues that the two sides would have to address over the course of FTA negotiations, they would have to contend with the political uncertainties of Brexit. Even though the deal would no longer involve the UK, Australia has not lost interest. On the contrary, the visit by the Australian Ministers for Foreign Affairs and Trade to the EU institutions in September 2016 confirmed that interest-a visit which the European Parliament's Committee on International Trade returned in late 2017. Nevertheless, Brexit is likely to delay Australia-EU negotiations because the UK, which is the EU member state most likely to gain from a prospective trade and investment agreement between Australia and the EU, will not participate. The UK's absence from the negotiations could reduce the initial level of ambition that both Australia and the EU had for the deal. The UK is Australia's largest bilateral EU trading and investment partner. With perhaps the exception of Germany, the other EU member states do not have such an important bilateral economic relationship with Australia.

In the meantime, Mr Turnbull has offered a country-to-country FTA to his UK counterpart, Theresa May, who found the offer 'very encouraging' ("Australia Eager" 2016). Indeed, the UK and Australia have established a bilateral Trade Working Group to study the prospect of a post-Brexit FTA. Legally, such an agreement would not be possible until after the UK withdraws from the EU and, in any case, does not preclude an Australia-EU FTA. The UK may pursue informal FTA negotiations with Australia, but the duty of sincere cooperation that the UK owes to the other EU member states while it remains an EU member state does not allow the UK to formally negotiate an FTA with Australia until after it withdraws from the EU. Whatever option the UK chooses-either to join the European Economic Area through the European Free Trade Association or to preserve its autonomy as a separate customs territory-a prospective Australia-EU FTA would not apply to it-not unless the UK enters into the agreement as a third party with the consent of both sides. The UK government's Minister of State for Trade Policy advised the UK Parliament's European Scrutiny Committee on 20 November 2017 that the UK Department for International Trade assumes that 'the UK is expected to 
have exited the EU ahead of [the] FTA entering into force, and may well have entered into formal FTA negotiations' with Australia before it does so. The UK government appreciates the 'political sensitivities ... around our known intentions to negotiate UK-Australia and UK-New Zealand FTAs once we have left the EU, and the trade dialogues that we have established with both' (European Scrutiny Committee 2017).

A further political issue is the residue of political animosity to FTAs that the signature of CETA has left in a number of EU member states because of their potential to impact adversely on economic sustainability and the right to regulate for the public interest. The difficulty that the EU encountered with national and subnational parliaments - the Belgian Walloon Parliament-to sign CETA is still recent. That difficulty, however, should not affect the proposed Australia-EU FTA, as it would be an EU-only mandate. As a fast-track FTA, it will exclude non-direct foreign investment and investorstate dispute settlement mechanisms, which are the only two areas of external economic regulation left within EU member states' competence. Of course, that limitation of scope will make the prospective FTA less economically ambitious.

\section{Conclusion}

Australia and the EU are economically interdependent. The EU, which is Australia's second-largest source of goods imports, supplies the capital goods that Australia's infrastructures need. The EU, which is Australia's largest partner for trade in services, supplies the professional services that drive a knowledge economy. And the EU, which is also Australia's largest investment partner, provides the credit to finance economic development. In parallel, the EU looks to Australia both as a commercial base in Asia and as a reliable energy supplier.

The strength of the Australia-EU trade and investment relationship drives their economic interdependence. The relationship, however, has not always been easy. Policy discrepancies over Australia's biosecurity system and the EU's agricultural protection system have been too close to the realm of economic sovereignty for the WTO legal framework that regulates the economic relationship to effectively address. Now that Australia and the EU finally recognise each other as close economic partners with common interests, values and heritage, a reset of the bilateral trade and investment relationship is timely. A deep and comprehensive FTA for sustainable interdependent economic growth and development has the potential to reset it.

\section{REFERENCES}

"Australia Eager to Start Free Trade Talks with Britain." 2016. Guardian, July 17. https://www.theguardian.com/politics/2016/jul/17/australiaeager-to-start-free-trade-talks-withbritain

Australian Government. 2012. Australia in the Asian Century. White Paper. Canberra: Commonwealth of Australia.

Barroso, José Manuel Durão, and Herman Van Rompuy. 2013. "Foreword: Commemorating 50 Years." In Celebrating 50 Years: EU-Australia, by Delegation of the European Union to Australia, 6-7. Canberra: Stroudgate. 
BCA (Business Council of Australia). 2008. Towards a Seamless Economy: Modernising the Regulation of Australian Business. Melbourne: BCA.

Benvenuti, Andrea. 1999. "Australia's Battle against the Common Agricultural Policy: The Fraser Government's Trade Diplomacy and the European Community." Australian Journal of Politics and History 45 (2): 181-196. doi: 10.1111/1467-8497.00061

Benvenuti, Andrea. 2007. “Facing the Inevitable: Britain's Entry into the European Community and Australia's Policy, 1970-72." Australian Journal of Politics and History 53 (3): 251-266. doi: 10.1111/j.1467-8497.2007.00458.x

Bhala, Raj. 2008. International Trade Law: Interdisciplinary Theory and Practice. 3rd ed. Newark, NJ: LexisNexis.

Bryce, Quentin. 2013. "Opening of the Inaugural Australia-Europe Leadership Dialogue." Speech, Brussels, June 5.

Burnett, Alan. 1983. Australia and the European Communities in the 1980s. Canberra: Australian National University.

Ciobo, Steven. 2017. "Working Towards an Australia-EU Free Trade Agreement." Business Envoy, December 21. http://dfat.gov.au/about-us/publications/trade-investment/businessenvoy/Pages/january-2018/working-towards-an-australia-eu-free-trade-agreement.aspx

Crean, Simon. 2008. "Launch of European Australian Business." Speech, Canberra, May 5.

Delegation of the European Union to Australia. 2013a. Celebrating 50 Years: EU-Australia. Canberra: Stroudgate.

Delegation of the European Union to Australia. 2013b. "The EU-Australia Economic Relationship." EU Insight, February.

https://eeas.europa.eu/sites/eeas/files/20130213_eu_australia_economic_relations_0.pdf

Department of the Prime Minister and Cabinet. 2014. Reform of the Federation White Paper: A Federation for Our Future. Issues Paper 1. Canberra: Commonwealth of Australia.

DFAT (Department of Foreign Affairs and Trade) and Austrade. 1996. Australia-European Union Trade and Investment: Towards 2000. Canberra: DFAT and Austrade.

DFAT (Department of Foreign Affairs and Trade). 1989. The European Community Single Market Program: Implications for Australia. Canberra: Commonwealth of Australia.

DFAT (Department of Foreign Affairs and Trade). 2012. Trade at a Glance 2012. Canberra: Commonwealth of Australia.

DFAT (Department of Foreign Affairs and Trade). 2015. International Investment Australia 2014. Canberra: Commonwealth of Australia.

DFAT (Department of Foreign Affairs and Trade). 2016. Composition of Trade: Australia 2015. Canberra: Commonwealth of Australia.

DFAT (Department of Foreign Affairs and Trade). 2018. Composition of Trade: Australia 2016/17. Canberra: Commonwealth of Australia. 
Directorate-General for Trade. 2017. "Ex-Ante Study of the EU-Australia and EU-New Zealand Trade and Investment Agreements: Executive Summary." Luxembourg.

European Commission. 2010a. "The CAP towards 2020: Meeting the Food, Natural Resources and Territorial Challenges of the Future." Communication from the Commission to the European Parliament, the Council, the European Economic and Social Committee and the Committee of the Regions. $\operatorname{COM(2010)~672,~Brussels,~} 18$ November 2010.

European Commission. 2010b. "Europe 2020: A Strategy for Smart, Sustainable and Inclusive Growth." Communication from the Commission. COM(2010) 2020 final, Brussels, March 3.

European Commission. 2015. "Trade for All: Towards a More Responsible Trade and Investment Policy." Communication from the Commission to the European Parliament, the Council, the European Economic and Social Committee and the Committee of the Regions. COM(2015) 497, Brussels. 14 October 2015.

European Commission. 2017a. "Annex I to the Recommendation for a Council Decision Authorising the Opening of Negotiations for a Free Trade Agreement with Australia." COM(2017) 472, Brussels. 13 September 2017.

European Commission. 2017b. "Executive Summary of the Impact Assessment Accompanying the Document Recommendation for a Council Decision Authorising the Opening of Negotiations for a Free Trade Agreement with Australia." Commission Staff Working Document. SWD(2017) 292, Brussels. 13 September 2017.

European Commission. 2017c. "Recommendation for a Council Decision Authorising the Opening of Negotiations for a Free Trade Agreement with Australia." COM(2017) 472, Brussels. 13 September 2017.

European Commission, European Council and Australian Government. 2015. "Statement of the President of the European Commission Jean-Claude Juncker, the President of the European Council Donald Tusk and the Prime Minister of Australia Malcolm Turnbull." November 15. Accessed 20 November 2017. https://publications.parliament.uk/pa/cm201719/cmselect/cmeuleg/301i/30143.htm

European Scrutiny Committee. 2017. "Opening of Negotiations for Free Trade Agreements with Australia and New Zealand." London.

Findlay, Christopher. 2009. "The Business Services Market in Australia and the EU: Opportunities for Growth." Paper presented at the Australian National University Centre for European Studies conference on "Trade and Investment Issues for the 21st Century: Building an Agenda for Australia/EU Cooperation," Canberra, November 17.

Hon Tim Fischer, MP. 1996. "Deputy Prime Minister and Minister for Trade, to the Australian Business in Europe Meeting." Sydney, 21 June.

Gelber, Harry. 1966. Australia, Britain and the EEC: 1961 to 1963. Melbourne: Oxford University Press.

Glyde, Phillip. 2008. "Agriculture: Narrowing the Gap by Changing the CAP." Paper presented at the Centre for European Studies-Australian National University symposium on "The European Union: Australia's New Business Horizon," Canberra, March 14. 
"Good on You." 2016. The Economist, September 3. https://www.economist.com/news/financeand-economics/21706262-australia-has-weathered-china-slowdown-and-commodities-slump-wellwhat-has-it.

Harding, Gareth. 2000. "Trade Cloud Looms over EU-Australia Talks.” European Voice. Accessed 26 January 2000. https://www.politico.eu/article/trade-cloud-looms-over-eu-australia-talks/.

Higgott, Richard. 1994. "Closing a Branch Office of Empire: Australian Foreign Policy and the UK at Century's End." International Affairs 70 (1): 41-65. doi: 10.2307/2620715

Jenkins, Roy. 1989. European Diary: 1977-1981. London: Collins.

Josling, Tim E. 2009. "Agriculture." In Bilateral and Regional Trade Agreements: Commentary and Analysis, edited by Simon Lester and Bryan Mercurio, 171-212. Cambridge: Cambridge University Press.

Kenyon, Donald. 2012. "Australia and the European Union: A Relationship Driven by Trade." In No Eutopia: The European Union Today edited by Australian Institute of International Affairs, 33-42. Canberra: Australian Institute for International Affairs.

Kenyon, Donald, and David Lee. 2006. The Struggle for Trade Liberalization in Agriculture: Australia and the Cairns Group in the Uruguay Round. Canberra: Department of Foreign Affairs and Trade.

Kenyon, Donald, and David Lee. 2011. "Australia and Europe." In Middle Power Dreaming: Australia in World Affairs 2006-2010, edited by James Cotton and John Ravenhill, 111-128. Melbourne: Oxford University Press.

Kunkel, John. 2003. "Perfidious Albion Revisited: Anglo-Australian Trade Relations and European Economic Integration." Paper presented at the Centre for European Studies, Australian National University, Canberra, April 4.

Miller, Nick. 2016. "European Parliamentarians Urge Australia to Put Planned Free Trade Talks with Britain on Ice." Sydney Morning Herald, September 9.

https://www.smh.com.au/politics/federal/european-parliamentarians-urge-australia-to-putplanned-free-trade-talks-with-britain-on-ice-20160909-grcbz7.html

Murray, Philomena. 2002. "Australia's Relations with the European Union: Branch Office or Independent Actor?" In Trade and Cooperation with the European Union in the New Millennium, edited by Cheryl Saunders and Gillian Triggs, 155-172. The Hague: Kluwer Law International.

Murray, Philomena. 2003. "Problems of Symmetry and Summitry in the EU-Australian Relationship." In Europe and the Asia-Pacific: Culture, Identity and Representations of Region, edited by Stephanie Lawson, 66-85. London: RoutledgeCurzon.

Murray, Philomena. 2005. Australia and the European Superpower: Engaging with the European Union. Melbourne: Melbourne University Press.

Murray, Philomena. 2008. Europe and Asia: Regions in Flux. Basingstoke: Palgrave Macmillan.

The Nationals. 2016. 2016 Policies: The Coalition's Policy for More Jobs and Growth through Increased Trade and Investment.

Nelson, Brendan. 2013. “National Press Club of Australia Address." Canberra, September 18. 
Oxley, Alan. 2002. "Australia and the European Union-Trade and Environment-Diverging Perspectives." In Trade and Cooperation with the European Union in the New Millennium, edited by Cheryl Saunders and Gillian Triggs, 107-112. The Hague: Kluwer Law International.

Raffin, Luke. 2007. "Indivisible Partners or Enduring Combatants? Divisions and Triumphs in the EUAustralian Relationship." Journal of Contemporary European Research 3 (2): 141-160.

Richardson, J. 1992. "Australia and Western Europe." In Diplomacy in the Marketplace: Australia in World Affairs, 1981-90, edited by Peter Boyce and John Angel, 208-224. Melbourne: Longman Cheshire.

Saunders, Cheryl, and Gillian Triggs. 2002. "Preface." In Trade and Cooperation with the European Union in the New Millennium, edited by Cheryl Saunders and Gillian Triggs, vii-ix. The Hague: Kluwer Law International

"Something Old, Something New." 2000. The Economist, September 7. https://www.economist.com/node/21542922

Vaile, Mark. 2004. “Australian Business in Europe." Speech, Canberra, May 13.

Villalta Puig, Gonzalo. 2008. The High Court of Australia and Section 92 of the Australian Constitution. Sydney, Australia: Thomson Lawbook.

Villalta Puig, Gonzalo. 2014. Economic Relations between Australia and the European Union: Law and Policy. Alphen aan den Rijn: Kluwer Law International.

Villalta Puig, Gonzalo. 2016. "The Need for a Trade and Investment Agreement between Australia and the EU." International Trade Law and Regulation 22 (3): 61-63.

Villalta Puig, Gonzalo. 2018. "Free Trade as an Australian Constitutional Value: A Functionalist Approach to the Interpretation of the Economic Constitution of Australia." In Australian Constitutional Values, edited by Rosalind Dixon, 287-304. Oxford: Hart.

Villalta Puig, Gonzalo, and Erik Mitbrodt. 2014. "Agricultural Trade and Economic Development: Contradictions and Incongruities between Law and Policy." In Handbook of the International Political Economy of Trade, edited by David A. Deese, 174-198. Cheltenham: Edward Elgar.

Villalta Puig, Gonzalo, and Bruno Zeller. 2016. "Border Barriers and Behind the Border Barriers in the Australia-European Union Trade and Investment Relationship." Submission to the Department of Foreign Affairs and Trade, Australian Government, Australia-European Union Free Trade Agreement. Canberra.

Ward, Angela. 2002. "'Collective Amnesia' of Europe v Engagement with Asia: Forging a Middle Path for Australia in the Age of Regionalism." In Trade and Cooperation with the European Union in the New Millennium, edited by Cheryl Saunders and Gillian Triggs, 173-196. The Hague: Kluwer Law International.

WTO (World Trade Organization). 2005. "European Communities-Export Subsidies on Sugar." Appellate Body Report, WT/DS265/AB/R, WT/DS266/AB/R, WT/DS283/AB/R, AB-2005-2, April 28. WTO (World Trade Organization). 2011. "Trade Policy Review of Australia: Record of the Meeting." WT/TPR/M/244, May 6. 
WTO (World Trade Organization). 2015. "Trade Policy Review of Australia: Report by the Secretariat: Australia: Revision.” WT/TPR/S/312/Rev.1, July 21.

WTO (World Trade Organization). 2017. "Trade Policy Review of the European Union: Report by the Secretariat: The European Union." WT/TPR/S/357, May 17. 